IJBPAS, December, Special Issue, 2021, 10(12): 311-318

ISSN: 2277-4998

International Journal of Biology, Pharmacy and Allied Sciences (IJBPAS)

'A Bridge Between Labottory and Qandor'

Www.ijbpas.com

\title{
A CROSS SECTIONAL STUDY OF ANALYSIS OF URINE AS THE DIAGNOSTIC TOOL FOR PRAMEHA-NIDAN
}

\section{AKSHAR ASHOK KULKARNI ${ }^{1 *}$ AND NEHA DATTATRAYA GADGIL ${ }^{2}$}

1: Associate Professor, Department of Kriya Sharir, Parul Institute of Ayurved \& Research, Parul University, Vadodara, Gujarat - 391760

2: Associate Professor, Department of Kriya Sharir, Parul Institute of Ayurved, Parul University, Vadodara, Gujarat - 391760

*Corresponding Author: E Mail: Akshar Ashok Kulkarni: draksharashok@gmail.com Received $9^{\text {th }}$ May 2021; Revised $10^{\text {th }}$ July 2021; Accepted 29 ${ }^{\text {th }}$ Aug. 2021; Available online $15^{\text {th }}$ Dec. 2021

\section{https://doi.org/10.31032/IJBPAS/2021/10.12.1028}

\begin{abstract}
'Prameha' is a condition mentioned in Ayurveda wherein systematic explanations about the abnormalities occurring in urine and the clinical interpretations of same are elaborated. This cross sectional study on 120 patients revealed that the Ayurveda Parameters viz. Mootrapramana (quantity of urine excreted), Mootra-Swaroopa (nature of urine), MootraVarna (colour of urine) and Mootra-Sparsha (temperature of urine) are the constructive tools to diagnose Prameha and its types.

Key words: Ashtavidha Pariksha, Dashavidha Pariksha, Mootra Pariksha, Urine analysis, Prameha, Prameha-Nidan
\end{abstract}

\section{INTRODUCTION}

According to Ayurveda there are various ways to examine a clinical condition [1]. Also, there are several factors to assess the clinical condition. E.g. Ashtavidha Pariksha [2] - to examine 8 factors viz. Nadi (pulse), Mutra (urine), Mala(stool), Jivha (tongue), Shabda (voice), Sparsha (touch), Druk (vision) \& Akriti (built), Dashavidha Pariksha [3]- to examine 10 factors viz. Prakruti (constitution), Vikruti (abnormalities), Sara (status of Dhatu tissues), Samhanana (built), Pramana (measures of vital factors), Satva (tolerance), Satmya (acceptability of 
body), Ahara Shakti (capacity to consume the food), \& Vyayama Shakti (physical strength). The solitary purpose of these examinations is to arrive at the appropriate diagnosis to treat the condition accurately. It is the fact that diagnosing and treating the cause of a disease is the comprehensive management of the disease.

'Prameha' is a condition mentioned in Ayurveda wherein systematic explanations about the abnormalities occurring in urine and the clinical interpretations of same are elaborated [4]. Along-with clinical examination the key diagnostic tools to be used to decide the type of Prameha are the factors related to Urine only. No other clinical features are explained as signs or symptoms [5]. Those which are explained are either prodromal symptoms or complications of the disease [6]. There are
Ayurveda Classics due to vitiation of Vata, Pitta \& Kapha, based on characteristics of urine excreted [7]. The primary criterion of diagnosis of Prameha is based on quantity of urine and frequency of urination [8]. When a person excretes excess quantity of urine than expected normal quantity which is 1 to 2 litres in 24 hours and also urinates more frequently than normal, it is called Prameha [9]. In a healthy Indian adult, 68 times in 24 hours is the normal frequency of urination [10]. In the current study an attempt is made to diagnose types of Prameha according to Ayurveda. For the same a pilot study is conducted to demonstrate the types of Prameha [11].

Objective of the study: To observe types of Prameha using Ayurveda parameters of urine examination.

\section{LITERATURE REVIEW:}

Types of Prameha -

20 types of Prameha described in

Table 1: Types of Prameha mentioned in Ayurveda Reference books

\begin{tabular}{|c|c|c|c|}
\hline Samhita & Charakasamhita & Sushrutasamhita & $\begin{array}{c}\text { Ashtanga Hridaya } \\
\text { Samhita }\end{array}$ \\
\cline { 1 - 2 } Types & & & Udak \\
\hline Kaphaja-10 & Udaka & Udak & Ikshu \\
\hline $\mathbf{2}$ & Ikshu & Ikshuvalika & Sandra \\
\hline 3 & Sandra & Sandra & Pura \\
\hline 4 & Sandraprasad & Pishta & Shukra \\
\hline 5 & Shukla & Shukra & Sheeta \\
\hline 6 & Shukra & Lavana & Sikata \\
\hline 7 & Sheeta & Sikata & Shanai \\
\hline 8 & Sikata & Shanai & Lala \\
\hline 9 & Shanai & Phena & Kshara \\
\hline 10 & Aalala & & Kala \\
\hline Pittaja-6 & & Kshara & Neela \\
\hline 1 & Kshara & Amla & Rakta \\
\hline 2 & Kala & Neela & Shonita \\
\hline 3 & Neela & & \\
\hline 4 & Rakta & &
\end{tabular}




\begin{tabular}{|c|c|c|c|}
\hline $\mathbf{5}$ & Manjishtha & Manjishtha & Manjishtha \\
\hline $\mathbf{6}$ & Haridra & Haridra & Haridra \\
\hline Vataja-4 & & & Vasa \\
\hline $\mathbf{1}$ & Vasa & Vasa & Majja \\
\hline $\mathbf{3}$ & Majja & Sarpi & Hasti \\
\hline 4 & Hasti & Hasti & Madhu \\
\hline
\end{tabular}

Table 2 - Diagnostic Features of urine mentioned in classics as per type of Prameha

\begin{tabular}{|c|c|c|c|c|c|c|c|}
\hline & कफज & वर्ण & स्पर्श & स्वरूप & गंध & रस & प्रमाण \\
\hline$?$ & उदक & सितम् & शीतम् & अच्छम्, उदकोपमम् & निर्गन्धम् & - & बहु \\
\hline २ & इक्षु & $\begin{array}{l}\text { कांडेक्षुरस- } \\
\text { संकाशं }\end{array}$ & $\begin{array}{l}\text { शीतम्, } \\
\text { ईषत्पिच्छिलम् }\end{array}$ & आविलम् & - & $\begin{array}{l}\text { अत्यर्थ- } \\
\text { मधुरम् }\end{array}$ & - \\
\hline ३ & सान्द्र & - & - & पर्युषितं सान्दीभवति & - & - & - \\
\hline$\gamma$ & सान्द्रप्रसाद & - & - & $\begin{array}{l}\text { किंचित् संहन्यते, } \\
\text { किंचित् प्रसीदति }\end{array}$ & - & - & - \\
\hline 4 & शुक्ल & शुक्ल & - & - & - & - & अभीक्ष्ण \\
\hline$\xi$ & शुक्र & $\begin{array}{l}\text { शुक्राभ } \\
\text { (स्फटिकाभ) }\end{array}$ & - & शुक्रमिश्र & - & - & - \\
\hline$७$ & शीत & - & शीत & - & - & $\begin{array}{l}\text { अत्यर्थ- } \\
\text { मधुरम् }\end{array}$ & भृशम् \\
\hline$c$ & सिकता & - & - & $\begin{array}{l}\text { मूत्रगतान् मूर्तान् अणून् } \\
\text { दोषान् मेहति }\end{array}$ & - & - & - \\
\hline$९$ & शनै: & - & - & - & - & - & - \\
\hline \multirow[t]{2}{*}{ १० } & आलाल & - & पिच्छिल & तन्तुबद्ध, लालाइव & - & - & - \\
\hline & पित्तज & & & & & & \\
\hline $9 ?$ & क्षार & क्षारवर्णी & क्षारवत् & - & क्षारगन्धी & क्षारवत् & - \\
\hline १२ & काल & मसीवर्णम् & उष्ण & - & - & - & अजसम् \\
\hline १३ & नील & चाषपक्षनिभम् & - & - & - & अम्ल & - \\
\hline 98 & रक्त & रक्तवर्ण & उष्ण & - & विस & लवण & - \\
\hline 94 & मক्जिष्ठा & $\begin{array}{l}\text { मांजिष्ठोदक- } \\
\text { संकाशम् }\end{array}$ & - & - & विस्त & - & भृशम् \\
\hline \multirow[t]{2}{*}{ १६ } & हरिद्रा & हारिद्रोदकसंकाशम् & - & - & - & कटु & - \\
\hline & वातज & & & & & & \\
\hline १७ & वसा & वसाभम् & - & वसामिश्र & - & - & - \\
\hline १८ & मज्जा & - & - & मूत्रेण सह मज्जा मेहति & - & - & - \\
\hline १९ & हस्ति & - & - & - & - & - & अजसं, भृशं \\
\hline २० & मधु & पाण्डु & रूक्ष & - & - & कषाय-मधुर & - \\
\hline
\end{tabular}

Table 3: Characteristic features of urine in each type of Prameha - consolidated

\begin{tabular}{|c|c|c|}
\hline Sr. No. & Type & Features of urine \\
\hline 1. & Udakameha & Clear, white, plenty, cold, odourless, watery, \\
\hline 2. & Ikshumeha & Sweet, cold, slightly slimy, turbid, slight greenish coloured \\
\hline 3. & Sandrameha & On stabilising overnight, precipitate is seen at the bottom \\
\hline 4. & Sandraprasad Meha & Mixture of precipitate and clear urine \\
\hline 5. & Shukla meha & White like mixed powder, \\
\hline 6. & Shukrameha & Excessive sweet \\
\hline 7. & Sheetameha & Drine containing substrates \\
\hline 8. & Sikatameha & Sticky urine having saliva like appearance \\
\hline 9. & Shanai Meha & Like kshara \\
\hline 10. & Alalameha & Black coloured, warmer than normal \\
\hline 11. & Ksharameha & Like chasha pakshi, Amla \\
\hline 12. & Kalameha & Foul smell, salty taste, warm, red coloured \\
\hline 13. & Nilameha & Orange coloured, foul smell \\
\hline 14. & Lohitameha &
\end{tabular}




\begin{tabular}{|c|c|c|}
\hline 16. & Haridrameha & Dark yellow, Pungent taste \\
\hline 17. & Vasameha & Vasamishra, \\
\hline 18. & Majja Meha & Majjanam Saha \\
\hline 19. & Hastimeha & Excessive Urination \\
\hline 20. & Madhumemha & Dry, pale, \\
\hline
\end{tabular}

Table 4: Medicine for each type of diagnosed Prameha mentioned in Sushrutasamhita [11]

\begin{tabular}{|c|c|c|}
\hline ९. & उदकमेह & पारिजात कषाय \\
\hline २. & इक्षुमेह & वैजयन्ति कषाय \\
\hline ३. & सान्द्रमेह & सप्तपर्ण कषाय \\
\hline ४. & सुरामेह & निम्ब कषाय \\
\hline 4. & शुक्लमेह & हरिद्रादारुहरिद्रा कषाय \\
\hline ६. & शुक्रमेह & दूर्वशैवलप्लवहठकरज्जकसेरुक, ककुभचन्दनकषायं वा \\
\hline$\vartheta$. & लवणमेह & पाठाउगुरुहरिद्रा कषाय \\
\hline ८. & सिकतामेह & चित्रक कषाय \\
\hline ९. & शनै:मेह & खदिर कषाय \\
\hline ९०. & फेनमेह & त्रिफलारग्वधमृद्वीका कषाय \\
\hline १९. & क्षारमेह & त्रिफला कषाय \\
\hline १२. & अम्लमेह & न्यग्रोधादि कषाय \\
\hline १३. & नीलमेह & शालसारादि, अश्वत्थ कषायं वा \\
\hline ९४. & रक्तमेह & गुडूचीतिन्दुकास्थिकाश्मर्यखर्जूर कषायं मधुमिश्रम् \\
\hline २५. & मक्जिष्ठमेहा & मञ्जिष्ठाचन्दन कषाय \\
\hline १६. & हरिद्रामेह & राजवृक्ष कषाय \\
\hline १७. & वसामेह & अग्निमन्थ शिंशपा कषायं वा \\
\hline ९८. & मज्जामेह & कुष्ठकुटजपाठाहि ड्गुकटुरोहिणीकल्कं गुडूचीचित्रककषाय \\
\hline ९९. & हस्तिमेह & तिन्दुककपित्थशिरीषपलाशापाठामूर्वादु :स्पर्शा कषाय \\
\hline २०. & मधुमेह & कदरक्रमुक कषाय \\
\hline
\end{tabular}

\section{MATERIALS \& METHODS:}

This study is carried out in the teaching hospital of BSDT's Ayurved Mahavidyalaya, Wagholi, Pune, on 120 individuals who were ready to participate in the study after informed written consent.

Inclusion criteria: The patients of either gender between the age group 18 years to 60 years having Prabhoota-Avila
Mootrata (excessive \& turbid urine) for more than 30 days were included.

Exclusion criteria: Patients on drugs \& diet which affect the quantity $\&$ colour of urine e.g. excessive water consumption, diuretics, Vitamin B complex, beetroot, sugarcane juice, coconut water, regularly consuming alcohol were excluded also the patients suffering from urinary tract infection, known patients of Benign 
Prostatic Hypertrophy, known patients of cancer of prostate gland were excluded.

Parameters for Assessment: Urine output $>3$ litres / 24 hours, frequency $>$ $10 / 24 \mathrm{hrs}$ for at least last 30 days. Quality of excreted urine Avila (turbid), Achcha (clear), Tantumatva (thready), Sandra (sediment), Mutra Varna (colour of Urine) Haridra (yellow), Manjishtha(orange), Ikshuvat (colour resembling the sugarcane i.e., light green), Rakta (red), etc. On the basis of these classical parameters the type of Prameha was diagnosed [12].

Lab Investigations - Blood sugar levels Fasting \& post meal, chemical \& microscopic examinations of urine were carried out.

Observations: This study was an attempt to find out types of Prameha based exclusively on classical Ayurved parameters of Prameha. The parameters described in Ayurved classics are Varna (Colour), Sparsha (temperature), Swaroopa (nature) \& Pramana of Mootra (quantity of urine excreted).

Out of 120 patients enrolled, 19 were of Sandrameha, 17 were of Alalameha, 15 were of Shuklameha, 14 each were of Haridrameha \& of Madhumeha. 11 were of Udakameha, 10 were of Sandraprasada. 7 were of Ikshumeha.. Shanairmeha, Ksharameha \& Sarpimeha were found in 3 patients each.
Phenameha was found in 2. Rakta \& Manjishtha were found in 1patient each.

Agni - the digestive capacity: In 112 patients, Agni was Vikruta. In 66 cases it was Manda. In 29 cases it was Vishama. In 17 cases Agni was Tikshna. Only 8 patients reported Sama-Agni - the normal status of digestive capacity. There is a vicious cycle between Agni \& Vikruta Kapha.

The chemical examinations of urine revealed no presence of abnormal substances like pus cells, blood cells, bacteria etc., in urine samples.

\section{DISCUSSION}

Manda Agni is responsible for Doshasanchiti (accumulation of Dosha). Because of which the Pachana Kriya (digestion) is affected [13]. Kledvruddhi (excessive unwanted moisture) occurs [14]. Ultimately the person becomes prone for Prameha. According to Ayurveda understanding of digestion and metabolism of food, the urine is separated during digestion as the liquid waste part of completely digested food [15]. During digestion, if the separation of urine is not properly done i.e. if it is separated with undigested particles in it, the formed urine becomes Saama - improperly formed from undigested food. Thus, Sara-Kitta Vibhajana (separation of essence and 
waste) from the food may result in variation in the nature of the urine [16].

Swaroopa (nature) of Mootra clear urine is considered as the normal urine. In Prameha it becomes turbid. It may be due to the presence of suspended particles present in urine due to involvement of [17] excessive Kapha Dosha in case of Prameha, excess and inappropriate Meda and Mamsa Dhatu in the body of patient of Prameha. Pishtanibha Mootra - cloudy urine may be due to Shweta Varna of Kapha Dosha. Tantubaddh - thread-like urine, Lala-Iva Swaroopa - sticky urine is due to Snigdha (unctuous) property of excess Kapha Dosha. Sandribhavana - precipitation in urine on stabilizing is due to Guru (heaviness) and Sthira (stable) properties of Kapha Dosha. Varna in various samples indicates the characteristic feature of vitiation in Teja Mahabhuta which points to Pitta-predominance resulting variation in the colour of the urine, especially in cases of Pittaja Prameha.

Mootra Rasa - taste of the urine - It was practically impossible to do Rasaparikshana (taste of Patients' urine). So it was not included in this study. Same was in case of Mootra Gandha examination of urine smell - Practically it was difficult to assess this subjective parameter. So this aspect was not the part of this study.

\section{CONCLUSION}

The Ayurveda Parameters viz. Mootrapramana (quantity of urine excreted), Mootra-Swaroopa (nature of urine), Mootra-Varna (colour of urine) and Mootra-Sparsha (temperature of urine) are the constructive tools to diagnose Prameha and its types. On the basis of the present cross sectional study an evidence for elementary signs \& symptoms of Prameha - 'Prabhoota-Avila Mootrata' - (excess \& turbid urine) is reestablished.

\section{Acknowledgement}

The authors like to acknowledge BSDT's Ayurved Mahavidyalaya, Wagholi, Pune, Maharashtra, for support and providing necessary facilities for this study, Dr. S. P. Sardeshmukh Sir, Chairman, BSD Trust, Wagholi, Pune \& Dr. Vineeta V. Deshmukh, Professor, Department of Samhita, BSDT's Ayurved Mahavidyalaya, Wagholi, Pune, Maharashtra, Dr. Sushant S. Bargale, Department of Swasthavritta, SDM College of Ayurveda \& Hospital, Hassan, Karnataka.

\section{REFERENCES}

[1] Acharya J T, editor. Charakasamhita. Reprint ed. Varanasi: Chaukhamba Surabharati Prakashan; 2016. Vimanasthana Chapter 4. Verse 1. 
[2] Joshi Sadaashiv Shastry, editor. Yogaratnakara, $1^{\text {st }}$ edition, Varanasi: Chaukhamba Sanskrit Series, 2004, Chapter 1.

[3] Kunte AM, editor. Ashtangahridaya. Reprint ed. Varanasi,Chaukhamba Surabharati Prakashan; 2018.Sutrasthana Chapter12. Verse 67, 68.

[4] Acharya J T, editor. Charakasamhita. Reprint ed. Varanasi: Chaukhamba Surabharati Prakashan; 2016. Vimanasthana Chapter 8. Verse 94. .

[5] Acharya J T, editor. Charakasamhita. Reprint ed. Varanasi: Chaukhamba Surabharati Prakashan; 2016. Nidanasthana Chapter 4.

[6] Acharya JT, editor. Sushrutsamhita. Reprint ed. Varanasi, Chaukhamba Surabharati Prakashan; 2014.Nidanasthana Chapter 6. Verse 4.

[7] Kunte AM, editor. Ashtangahridaya. Reprint ed. Varanasi,Chaukhamba Surabharati Prakashan; 2018.Nidanasthana Chapter10. Verse 38,39 .

[8] Acharya J T, editor. Charakasamhita. Reprint ed. Varanasi: Chaukhamba Surabharati Prakashan; 2016. Nidanasthana Chapter 4. Verse 3.

[9] Kunte AM, editor. Ashtangahridaya. Reprint ed. Varanasi,Chaukhamba Surabharati Prakashan; 2018.Nidanasthana Chapter10. Verse 7.

[10] Gyton Arthur C. \& Hall John E., Authors, Textbook of Medical P $11^{\text {th }}$ edition 2006, Elsevier Saunders, Philadelphia, Pennsylvania 19103. 2899, Page No. Chapter 28, Page No.357

[11] Joshi Y.G. editor, Kshemakutuhal by Kshemaraja Sharma, $1^{\text {st }}$ edition,2004, Pune Sahitya Vitarana,Pune, Chapter 5 Verse 93

[12] Acharya JT, editor. Sushrutsamhita. Reprint ed. Varanasi, Chaukhamba Surabharati Prakashan; 2014.Chikitsasthana Chapter 6.

[13] Acharya J T, editor. Charakasamhita. Reprint ed. Varanasi: Chaukhamba Surabharati Prakashan; 2016. Nidanasthana Chapter 4. Verse 12. 22.

[14] Acharya J T, editor. Charakasamhita. Reprint ed. Varanasi: Chaukhamba Surabharati Prakashan; 2016. Chikitsasthana Chapter 5. Verse 136.

[15] Acharya J T, editor. Charakasamhita. Reprint ed. Varanasi: Chaukhamba Surabharati Prakashan; 2016. Nidanasthana Chapter 4. Verse 8.

[16] Neha Dattatraya Gadgil et al. Development of an objective parameter for agni parikshana with reference to jaranakala of unit quantity of lajamanda. Int. Res. J. Pharm. 2019;10(3):242. 245 http://dx.doi.org/10.7897/2230. 8407.1003112

[17] Neha DattatrayaGadgil: Understanding Symptoms of 
Digestion in Ayurvedic Perspective ayurpub2016;I(5):242. 245

[18] Acharya J T, editor. Charakasamhita. Reprint ed. Varanasi: Chaukhamba Surabharati Prakashan; 2016. Nidanasthana Chapter 4. Verse 6, 7. 